\title{
ADVANCED AUTOMOTIVE PROPULSION SYSTEMS: INCENTIVE FINANCING
}

February 1979

\section{U.S. DEPARTMENT OF ENERGY}

Assistont Secretory for Conservation and Solar Applications

Division of Transportation Energy Conservotion

Washington, D.C. 20545 


\section{DISCLAIMER}

This report was prepared as an account of work sponsored by an agency of the United States Government. Neither the United States Government nor any agency Thereot, nor any of their employees, makes any warranty, express or implied, or assumes any legal liability or responsibility for the accuracy, completeness, or usefulness of any information, apparatus, product, or process disclosed, or represents that its use would not infringe privately owned rights. Reference herein to any specific commercial product, process, or service by trade name, trademark, manufacturer, or otherwise does not necessarily constitute or imply its endorsement, recommendation, or favoring by the United States Government or any agency thereof. The views and opinions of authors expressed herein do not necessarlly state or reflect those of the United States Government or any agency thereof. 


\section{DISCLAIMER}

Portions of this document may be illegible in electronic image products. Images are produced from the best available original document. 


\section{NOTICE}

Thil report we properted as in wexount of werk pontored ty the United Statts Govementint. Meither the United Slatm nor the United

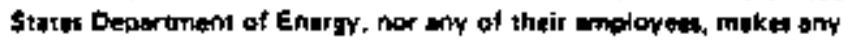

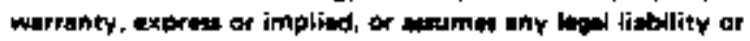

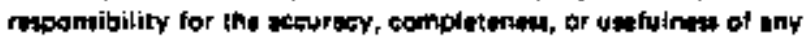

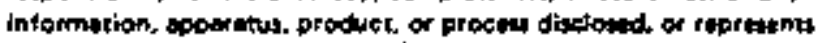

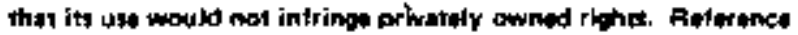

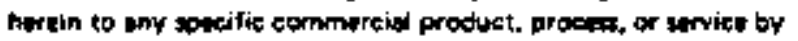

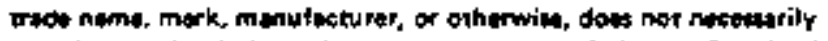
constiv ke or tmply its endorsement, recommendetion. of fevoring by

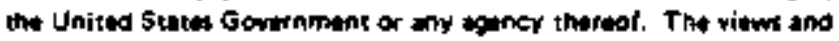

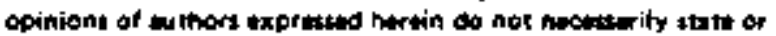

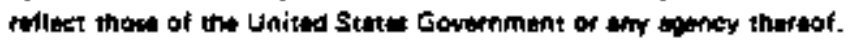

Available from:

National Techrical Information Service (NIIS)

U.S. Department of Commerce

5285 Port Royal Rozd

Epringfield, Yirginia 22161

Price: Priated copy: 6.00

Microfiche: $\$ 3.00$ 
TABLE OF CONTENTS

Sextion

Table of Contents

i

List of Figures

Executive Surnmory

iii

Intraduction

I.I Overview

I.2 Autarnotive Prooulsion Research and

Development Legislation

1.3 The AAPS Program

1.4 The AAPS Survey and Study

II

Bockground

7

2.1 Ceneral

2.2 Advanced Automotive Propulsion 5ystems

2.2.1 Gos Turbine Engine

2.2.2 Stirling Enginề

2.3 Autornotive Industry

2.3.1 Vehicle Manufacturers

2.3.2 Component Monufocturers

2.3.3 Reseorchers and Developers

2.4 Federal $F$ inoncial Incentives

(n)

Doto Collection and Discussions

19

3.1 Methodology

3.2 Literoture Review

3.3 Identification of Potential Study Participants

3.4 Identificotion of issues

3.5 Individual and Group Discussions

IV

Conclusions

$2 \circ$

4.I Introduction

4.2 Basic Issues

4.3 Technicol Development Conctusions

4.4 Applicability of incentives

Recommendations

5.1 Introduction:

5.2 Recommendations 
TABLE OF CONTENTS (CONTINUED)

Section

- Appendix A

Appendix $B$

Appendix C

Appendix D
Literature Reviewed

Federal Loan Guarantee Programs and Federally Insured Loon Programs

interested Parties

Points of Contact
Page

41

47

55

$6 !$

ii 


\section{LI5T OF FIGURES}

Figure

2.1

3.1

4. 1
Finoncial Incentives for Progrom Phoses

Methodology

Reiationship of Type of Finonciat Incentive to the Development Stoge of Advanced

Automotive Propulsion Systems $\underline{\text { Poge }}$

|a

22

34 
EXECUTIVE SUMMARY

v

-

! 


\section{EXECUTIVE SUMMARY}

At present, close 10 half of the oil used in the United States is imported. The lorgest single demond for oit comes from the tronsportotion sector, where internal combustion highwoy vehicles require about 7.5 mition borrels per doy. In order to reduce this high demand, Congress has outhorized a program of reseorch and development dealing with odvanced automotive propulsion systems (AAPS). In compliance with the "Autamotive Propulsion Research and Development Att of 1978," Title III of Public Low 95-238, the Department of Energy (DOE) is undertaking exponded research to develop and demonstrote advanced propulsion systerns by 1983. Section 310 (b) of the Act requires the Secretary of Energy to determine whether and under what conditions AAPS development could be aided by a Federal loon guor ontee progran, and to report his findings and recommendations to the Congress within one yeot from the dote of enoctment. In making this determination, a survey and study were mode to:

- Anolyze the use of vorious forms of Federal finoncial incertives, including loon guorantees, in relotionship to the development stoges of o new technology. (Section 2)

- Elicit comments ond opinions on the AAP5 \$tate-ot-the-ort and the perceived usefulness of loan guor ontees from inembers of the outanotive industry, reseorch organizations, and the finoncial community. (Section 3)

- Formulate conclusions and recommendations for transmittel to Congress on the odvisobility of using loon guorontees to oid AAPS development. (Section 4 and Section 5)

In general, the forms of Federal financial incentives which ore oppropriate to oid new technology development depend on the sloge of development of the technology and the copital requirements of the industry which will utilize that technology. The AAPS's are in early engineering development, where Federal grants and contracts ore currently in effect. Cost sharing ogreements ond tox incentives moy be appropriote depending on the specific circumstances.

A number of conclusions hove been derived. From o technical development slondpoint, it is opporent that AAPS's offer the potential of improved fuel economy, 
multiftrel copability, and reduced exhaust emisstion. Some problems exist, but these are not insurmountable and efforts to find acceptable solutions are continuing. The mojor antomotive producers probably would not need or use loon guorontees to develop AAPS's. However, the component morufocturers moy be interested in loan guorantees to satisfy the requirements of the industry. The finonciol community supports financial incentive programs for the outomobile industry if they provide adequate protection and sofeguards of investments.

Bosed on these conciusions and in view of the current state of technological development, which is olreody supported by Federal grants and coniracts, and the probability of only starting limited production late in the next decode, it is recommended that consideration of legistation for outharizing Federal loan guorantees in connection with advanced outomotive propulsion systems be deferred of this time.

While loon guorontees would not be on effective incentive during the present phase of AAPS development, DOE should evoluate the need for financial incentives, including loon guorantees, periodically. 


\section{SECTION I}

INTROOUCTION

- - 


\section{SECTION I \\ INTRODUCTION}

\subsection{Overview}

The growing dispority between energy supply and demand in the United States has caused increased concern and pasitive oction by Government policymokers in recent yeors. Over time, economic growth and increoses in population have odded large incrertents to an aiready large base of domestic energy consumption. Oil and natural gas ore receiving particular attention, since petroleum-bosed fuel supplies are in a stote of flux.

At present, close to half of the oit used in the United States is imported. In the neor term, energy dernond in the Nation will continue to require increosed ail imports until such time as domestic energy conservation programs and alfernative sources of energy are developed. In the long range, wortdwide demand for oil may exceed ovoilable resources.

Energy consumption in the United States is generally cotegorized into three brood sectors: (1) buildings and community systems, (2) industry, and transportation. While energy supplies in the first two sectors may be portially derived from cool, otomic power, and other nonpetroleum sources, almost all the fuel used in trassportation is derived from petroleum. This amounts to about half of the petroleum demand in the U.S. Energy-related legislation in recent years hos therefore ploced a strong emphosis on conservation in the transportation sector, with special emphosis on highwoy vehicles, which currenfly consume 7.5 million borrels of oil per day. $1 /$ Several lows passed by recent Congresses contoin provisions to curb energy consumption by highwory vehicles. Among the laws passed, the following address aspects other than heat ongine propulsion systems.

- Public Low 93-275, "The Federal Energy Admithistrotion Act of $\$ 974, "$ establishes orograms to educate motorists in energy conservotion tectniques

- Public Law 93-319, "Energy Supply and Environmental Coordination Act of 1974," mandates studies of fuel economy improvernent stondards in new motor vehicles 
- Public Low 94-163, "The Energy Policy and Conservation Act," promotes van pooling and car pooling, and permits the establishment of a program to increase transportation expertise at the Stote level

- Public Low 94-4/3, "The Elestric and Hybrid Vehicle Research, Development, and Demonstration Act of 1976," promotes the integration of electric and hybrid vehicles into the Notion's tronsportation fleet

- Public Law 95-619, "The National Energy Conservation and Policy Act," requires fuel economy labeling for outomobiles.

\subsection{Automotive Propulsion Research and Development Legislotion}

Continuing the effort to improve the national energy posture, the Congress enacted Public Low 95-238, "The Deportment of Energy Act of 1978-Civilian Applications." Title III of the low deals with automotive propulsion research and development. Referred to as the "Automotive Propulsion Research and Development Act of 1978," this title expresses the findings of the Congress thot:

- Existing aytornotive propulsion systems fall short of meeting the long-ferm gools of the Notion with respect to environmental protection and energy conservation.

- With sufficient research and development efforts, odvanced alternotives to existing outomotive propulsion systems could meet these long-term gools.

- Insufficient resources are being devoted to this effort.

- An exponded research and development effort coutd complement and stimulate corresponding efforts by the peivate sector, and would encouroge outomobile monufocturers to consider incorporating such advanced technology into outomabiles and outornotive comporents.

\subsection{The AAPS Progrom}

Bosed on such findings, the Congress has directed the Secretary of Energy to establish a program to ensure the develooment of odvanced automotive propulsion systems (AAPS) within 5 yeors, or as soon as practicoble. Current Government $\operatorname{costs}^{2 /}$ are estimạted to be:

\section{$2 /$ Ibid, poge 2-1.}


- \$1 25 Million for the Gos Turbine Project

- \$100 Million for the Stirling Engine Project.

In carrying out those responsibilities, the Secretary of Energy is outhorized and directed to make controcts and grants with Federal agencies, loboratories, universities, other organizations both public ond private, or individuais, for research and development leading to advanced automative propulsion systems that are likely to help meet the Notion's long-term gools, The objectives are to:

- Helo provide the necessory system technology to assist industry in the decision process on moss production by 1983

- Reduce petroleun requirements through efficient propulsion systems which may also use alternative non-petroleurn-based fuels

- Meet the most stringent automotive emission standards as established in the Cleon Air Act (42 U S.C. 1857 et seq.).

While the Congress has approved and, indeed, has directed the use of Federal contracts and grants as incentives for research and development associoted with advanced autamotive propulsion systems, it has directed that a study be made of Federal guarantees of financial obiligations. 5ection 310 (b) of the Automative Propulsion Reseorch and Development Act requires the Secretary of Energy to conduct a survey of developers and lending institutions and to make o study to determine whether, and under what conditions, research, development, demonstrotion, and commerciol availability of advanced automotive propulsion system tectrnology moy be aided by the guarontee of financial obligations by the Federal Government. Section 310 (b) further requires the Secretary to submit a report of the results of the survey ond study within one year from the date of emoctment.

\subsection{The AAPS Survey and Study}

The purpose of this survey and study was to: review the avoilable literature; contoct developers, lending institutions, and other interested porties to 
defermine their perceived need for Federal guarontees of financial obligations for AAPS research, development, demonstrations, and commercial avaliability; analyze the results; formulate conclusions; and make recommendations. A secondary purpose of the effort was to establish a dialogue with members of the outomotive industry and the financial community which would facititate development and ropid implementation of AAPS energy conservotion progroms. This report presents the results of the surver and study.

A background review of the cormplexities of odvanced automotive propulsion systems and of financiol incentives is presented in Section 2 of this report. Section 3 sets forth the methodology employed in developing the moterial for the report and reviews the information gathered through literature review, and individuol and group discussions. The conclusions drown from this informotion ore summorized in Section 4, leading to the recommendations mode in Section 5. Additionally, comprehensive appendices are provided for reody reference and eose in understanding the report. 
SECTION 2

BACKGROUND

$-7=$ 


\section{SECTION 2}

BACKGROUND

\subsection{Generat}

This section presents background informotion ossociated with this survey and study of advanced automotive propulsion systems (AAPS). Three aspects of AAPS are oddressed: technical, industrial, and Federal financial incentives. A brief technical discussion of AAPS is presented, followed by an overview of the automotive industry. Finoneing and the role of Federal financial incentives in energy conservotion projects are then addressed.

\subsection{Advanced Automotive Propulsion Systems}

Since 1971, vorious Federal ogencies have evoluated olternatives to the conventional internal combustion engine (ICE). From these evaluations, the heat engine systems which met all long range conservation, environmentol and standards were the Brayton (gos turbine) and 5tirling engines. While there ore other advanced - owtomotive heat engines such as the stratified-chorge Otto, atvonced diesel, and Ronikine engines, which are being pursued by the outomotive industry, they will not meet all long range national objectives of reducing petroleum consumption by 30 percent, by 1985, and elimination of petroleum as their prime energy source by 2000. Electric and hybrid propulsion systems development is under the oegis of another Department of Energy (DOE) program. This report focuses on financial incentives, porticularly loon guarantees, in the development of the Broyton and Stirting engines. These advanced heat engine power systems are aimed for commercialization during the $1985-2000$ interval.

DOE progroms are now focused on engineering development of gas turbine and Stirling engines to provide goad fuel efficiency, multifuel copobility, low emissions, and competitive cost. The gas turbine and stirling engines ore broodly defined and discussed in the following paragraphs.

\subsubsection{Gas Turbine Engine}

The Brayton engine, known as the gas turbine orgine, is an ICE that produces power by the exponsion of not combustion gases passing through a turbine. A portion of the output of the furbine is used to compress the inlet oir. in 
configurations under development for outomotive propulsion applications, the exhasst gases from the turbine pass through a regenerotor which octs to preheot incoming oit. (For more detail see Sowyer's Gos Turbine Engineering Honobook, Volumes I, II, and III, Business Journals Incorporated, 1972.)

To be o viable contender for future outomotive markets, the advanced gas turbine engine will need to be mechanically simple, lightweight, and economical. It will have to offer a significunt economic advantage over future generation internal combustion engines.

\subsubsection{Stirling Engine}

A Stirling engine is o closed cycle mochine which converts thermal energy to mechanical work by afternately compressing and expanding a confined working fluid with heot rejection during compression and heot addition during expansion. The cyclic movernent of the working fluid in the engine is occomplished by volume chonges in the working volume rother than intermittentily elosed volves. The cycle includes thermal regeneration, which is accomplished with o storoge heot exchanger that removes heat from the working fluid after expansion and returns heat to the working fluid ofter compression. (For more detajl, see Automotive Technology Status and Projections, Volumes $\mathrm{I}$ and II, Jet Propulsion Laboratory Publication, $78-$ 71.)

The need to conserve energy hos heightened the interest in the Stirling engine becouse of the engine's high thermodynamic efficiency. Stirting engine tectinology has been available for many years but has been undeveloped. However, efforts are underway to refine and improve the 5 tirting engine as a power sarce for several applicotions, inciuding automotive. These efforts have demonstrated the potential of the Stirling engine as a highly efficient condidate for the future. The recent interest in reducing petroleum use has generated severol new reseorch programs on the Stirling engine, both anolytical and experimental.

\subsection{Automotive Industry}

Currently, much of the research and development of AAPS's involves the established automotive industry. Mony of the major developmental contracts are 
given to the industry; the rotionole being thot the industry will eventuolly commercialize the techrology. For the purposes of this report the industry has been divided into three segments: vehicle manufacturers, component manufocturers, and researchers and developers.

\subsubsection{Vehicle Manufocturers}

The automotive industry in the United States consists of the four major cor producers-Chrysler, Ford, Generrol Motors, and, to a lesser extent, American Motors. Additionally, there are several other smaller, more specialized firms such as Checker Marathon and certain custom vehicle monufocturers. Most of the research effort on advanced propulsion systems is being conducted by the three largest producers. Chrysier and Ceneral Motors have research underwoy in the development of o gas turbine engine, while Ford is concentrating on its own PROCO design, which is o programmable ICE. Ford has also been developing \$tirling engines, but recently indicated that It would ceose further efforts on this progrom. Ford does continue to support development of components for Stirling engines, specifically in the orea of ceramic regenerotors.

\subsubsection{Component Monufocturers}

The component manufacturers inelude those firms producing items such as combustors, heot exchongers, transmissions, and other components. Manufocturers of materials for these components are also included under this cotegory. In foct, materials manufocturers may play the leoding role in early development of acceptable systems. New ceromic moterials for gas turbine engines and speciolty stainless steets for Stirling engines ore needed. These components must be copable of meeting extremely high temperatures during engine operations and also meet stringent mochining requir ernents.

\subsubsection{Researchers and Developers}

Most reseorch and development efforts in AAPS's are conducted by automobile manufocturers, component monufacturers, Federol laboratories, universities, private laboratories, and individual researchers. Federal laboratories 
are mentioned here solety to recognize their input to oul omotive propulsion systems and not as entities which might be recipients of financial assistance.

\subsection{Federal Financiol Ancentivers}

It is usuolly costly and risky to implement plons for product improvement, process improvement, and new product development. The informotion presented here is intended to focilitate o greater understanding of Federal financial incentives ond how they aply to AAPS projects.

NASA's Jet Propulsion Laboratory (JPL) has derived some cost comparisons for various types of automotive engines, comporing the variable costs, selling prices, price differentials and price increase foctors. The report indicates that the estimated price difference between the Brayton (gas turbine) engine and the conventional gosoline engine is $\$ 500-600$ (1977 dollors) for a full-sized car. The Stirling engine is estimated to be $\$ 800$ higher in the 100-150 hp size ronge. Even though engine costs only amount to about to percent of the cost of a full-sized car, investments in reseorch and development ore needed to moke these AAPS's more cost competitive to accelerate their commercializotion. (For further detail, see Energy Systems Acquisition Project Plon, Tronsportation Energy Conservation Division, Deportment of Energy, December I, 1978.)

The Federal Government can be a major source of research and development funds. In the interest of nationol economic growth and pressing notional needs, the Government often funds private sector industriol research ond develooment efforts. Other financial incentives hove been applied when it was in the notional interest to motivote industry to develop new or improved products. Resecrch and development efforts often involve risks greater than investors ore wilfing to assume, since such efforts sefdom produce revenue. The Federal Government has often assumed or defrayed some portion of extraordinary risks, while depending on industry and private copital to assume the ordinary investrment risks and to take responsibility for the design and operation of the projects.

There ore procedures by which the Government con shore risks. Riskshoring should incorpor ote basic objectives which include:

- A program to provide sufficient incentive to attract private copital 
- A risk-sharing progrom that is simple to odminister, under which private invertors and the Government know exoct ly whot they con expect and whot risks they will beor

- A program seen by Congress and the public os foir and equitoble. The Government should not essume all the risks while all the profit goes to industry (ideolly, alt the parties share both risks and rewards).

- Provisions for the withdrowol of Government participution when the risks hove been reduced to manogeoble levels through operating experience.

The Govermment con provide risk porticipation on either a project-byproject basis or 0 more general peogram basis. Provisions and conditions are contingent on the typies of risks involved. The perceived risks could opply to future market prices, technologicol uncertointies, cost of production focilities, or uncertointies regarding future Government regulatory actions.

A wide range of Federal programs has been developed that offects both the onount of copital formation and the allocotion of copital anong potential projects. These includes

$\begin{array}{ll}\text { - Tax incentlve programs } & - \text { Putchase agrements } \\ \text { - Controcts } & - \text { Direct loons } \\ \text { - Cost shoring } & - \text { Loon guorantees } \\ \text { Grants } & - \text { Price supports }\end{array}$

In general, the appropriate form of financial incentive for commerc alization of a new energy technology is releted to: (1) the technological, economic, and market feasibility of the energy project; (2) the length of time required for commercialization and (3) the credit standing and manogerial, financial and technical needs and expertise of the developing industry or firm.

Figure 2.1 shows five chronological phoses leading to the commercialization of a new technology: Research and Development, Prototype Development, Demonstration, Limited Production, and Full Production. The types of incentives are listed in the left column. Their coplicability to each program phose is indicated by a solid horizontal line, a broken line, or a blank space. A solid 


\section{FINANCIAL INCENTIVES FOR DEVELOPMENT/ COMMERCIALIZATION STAGES}

Figure 2 i

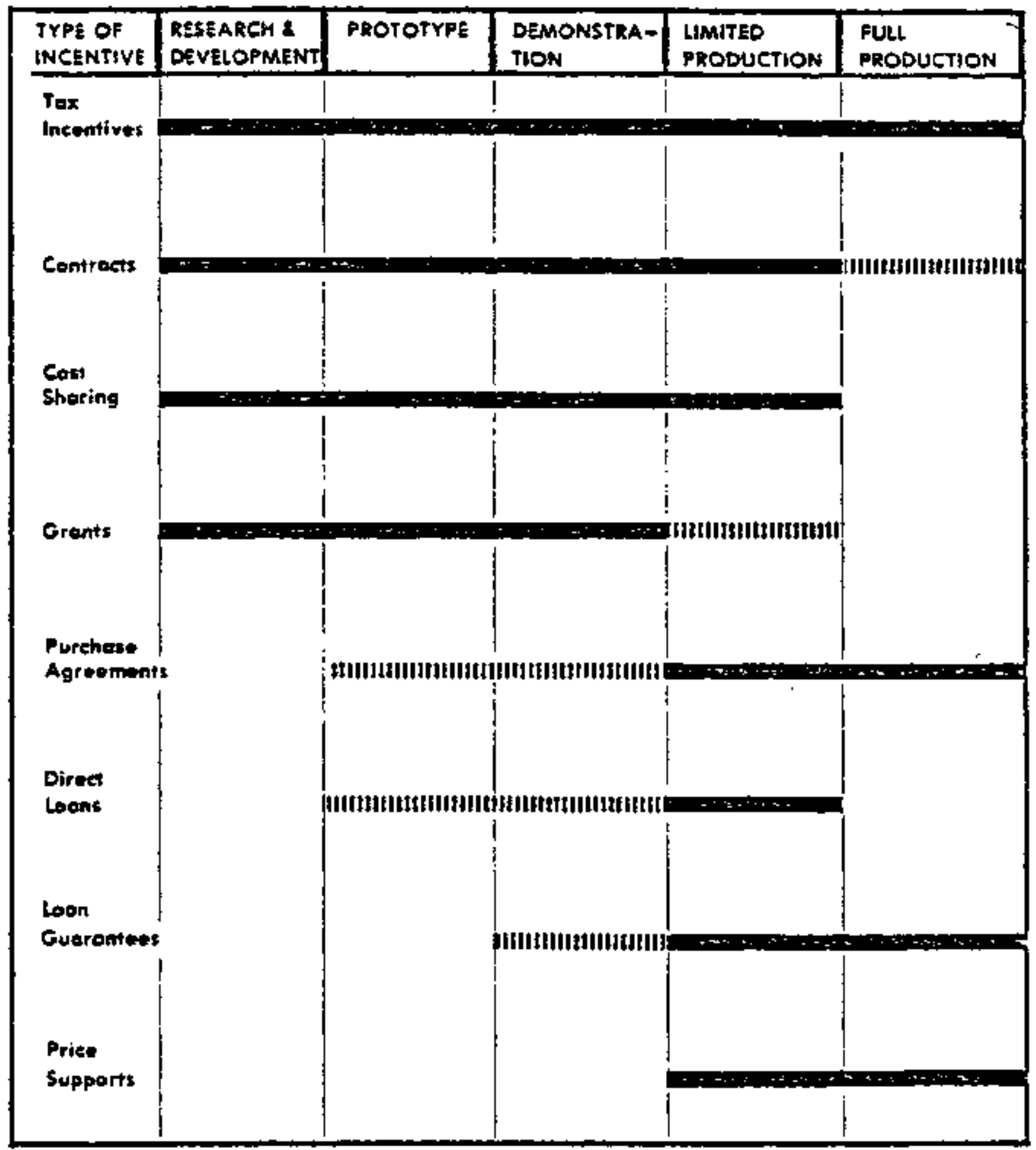

K*Y:

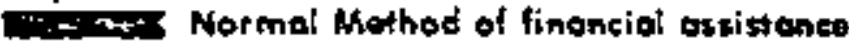

IItIIIIHII Alternote mathod of arsistence 
line indicates thot a specific incentive may be applicable in a specific phose. A broken line indicutes thot on incentive moy be applicable under certain alternate circumstances. A blark spoce shows that the incentive moy not be oppropriate for thot phase.

Tox incentives con serve to increase and sustain private sector investment in technolagical developments. These incentives may be porticularly useful to firms with fixed or limited budgets for R\&D ond/or new product development. A reduction in taxes essentially increases the copital ovailable for a firm to expand, intensify, or continue desired programs. Tax incentives may be oppropriate throughout the entire commercialization process when substantial anounts of copitol are invested in fixed assets. However, firms must hove sufficient revenues and profits to use tox incentives effectively, and this factor con limit the value of certain tax incentives to less profitable firms and to specialized ventures. Also, the costs and benefits of tox incentives tend to becorne permanent once instituted.

The Federal Government's share of $r$ isk and cost outloy is usually greater in the early phoses of development, when the end product is for trom commercializotion and the risks are higher. In the early phases of technological development, through the Limited Production phase, controcts moy be useful forms of Federal finoncial assistance. As the project progresses, the Federal risk could be reduced to a point where other forms of ossistance moy be more oppropriate. Reseorch and development contracts may in some coses continue to be appraptiate to sustain efforts during the Full Production phose.

Federal cost-stharing incentives may be used to stimulate technological development. Forms of cost-sharing moy be opplicable from Research and Development to the beginning of a tecthology's Full Production phase, or earlier, whenever the tectuological progrom becorres self sustaining. The potential benefits af cost sharing are: (I) there should be an occeleration and cross fertilization of public and privote research and development; (2) the cost sharing increoses capital avaitability to the private sector; and (3) the Federal Government has reasonable assurance of achieving its goois. The potential problems of cost shoring ore: (I) it could distort the normal flow of capital in private sector financial markets; (2) Federal Government participation could be jeopardized by failure of the project; (3) the private financial markets would not goin signifjcont experience in financing the new technology; and (4) the requirements for Federal and private sector coordingtion would involve substantial odministrative expenses. 
Grants, which provide front-end copital and solve the probleris of copital ovailability and exposure, may be appropriate from the start of the Research and Development phose through the end of the Demonstration phase. Grants can, in some coses, olso be useful forms of Federal assistance duting the Limited Production phase. However, grants could distort the normal flow of capital in private sector financial markets, and if loosely constructed and monitored, moy not ochieve Federal gools.

Purchase agreements, while sometimes useful during the Prototype and Demonstrotion phoses, moy be especially appropriote during the Limited and Fult Production phases. They moy assist firms roising capital and they should permit o sot isfoctory refurn on investment. On the negative side, purchose ogreements could generate Federal administrative difficulties and expenses. Also, they would not reduce capital exposure in the cose of production interruption or foilure.

Direct loons, with possibie interest subsidies, may serve as incentives from the Prototype phase through the Limited Production phase. The primary probiems with direct loons are the private sector financial institutions do nat get ocquointed with the needs and potential of the emerging technology, and the Federal Government bears oll of the risks and incurs substontial odministrative costs.

Federal loan guarantees can be appropriate during Limited Production and Full Production as long as the project will generate suffictent revenue to repoy the loan, both priscipal and interest. Loon guarantees may odidress the industry's copital ovalobility and protection needs, and may provide the impetus for rapid cornmercialization of a feasible technology. In oddition, Federal front end costs are low, ond administrative costs may be low if guarantee fees cover those cosfs. Both industry and the Federal Government shore the risk of development if private equity is required in the project. On the other hand, loan gubrantees do not address the problem of profitable operations. They presuppose on effective credit screening by lenders when it is possible thot lenders ore lax in their credit evoluations. Moreover, if the tectunical and finoncial aspects of a proposed project ore not thoroughly examined, loon guorantees may, in reatity, result in the inefficient allocotion of resources.

Price support incentives become applicable dur ing the Limited Production and Full Production phoses of product development. Becouse consumers are 
reluctont to accept new technologies and/or new products, price supports can play an important role in acceierating and continuing mass production and commer cializotion. They provide o guaranteed rote of return, enhonce profitability, and reduce the risk of financing. On the other hand, price supports could distort normal flow of capital in private sector financial markets, moy entail substontial Federal costs and continuing administrative requirements, and ignore problems of capital exposure. 


\section{SECTION 3}

DATA COLLECTION AND DISCUSSIONS

$$
-19
$$




\section{SECTION 3}

\section{DATA COLLECTION AND DISCUSS!ONS}

\subsection{Methodology}

In sotisfying the requirements of Section $310(b)$ of the Automotive Propulsion Research and Development Act of 1978, the survey and study conducted included the following steps:

- Literature review

- Identification of potentiol participating organizotions within the outomotive industry and the finarsiol community

- Identificotion of issues relating to Federal guorantees of financial obligotions for AAPS research and development

- Data collection through individual and group discussions with members of privete sector orgonizotions, officials of DOE, and other Federal agencies

- Data analysis and formulation of conclusions

- Recommendations.

The methodology employed in preparing this report is graphically depicted in Figure 3.1.

\subsection{Literature Review}

One of the exply steps in the collection of data was to examine literature which would impoct on an AAPS Federal guarantee progrom, if one were outhorized (see Appendix A). The literoture examined included technical informotion and information concerning existing Feder of financial incentives.

The tectinical information oddressed three aspects of odvanced automotive propulsion: (1) the overall program for odvonced automotive propulsion systems; (2) the state-ot-the-ort; and (3) the goals of the Federol government and the automotive industry in terms of dernonstration and commercialization of gas turbine and Stirling engines. The financiol literoture provided insight into high risk sechnology 


\section{METHODOLOGY}

Figure 3.I

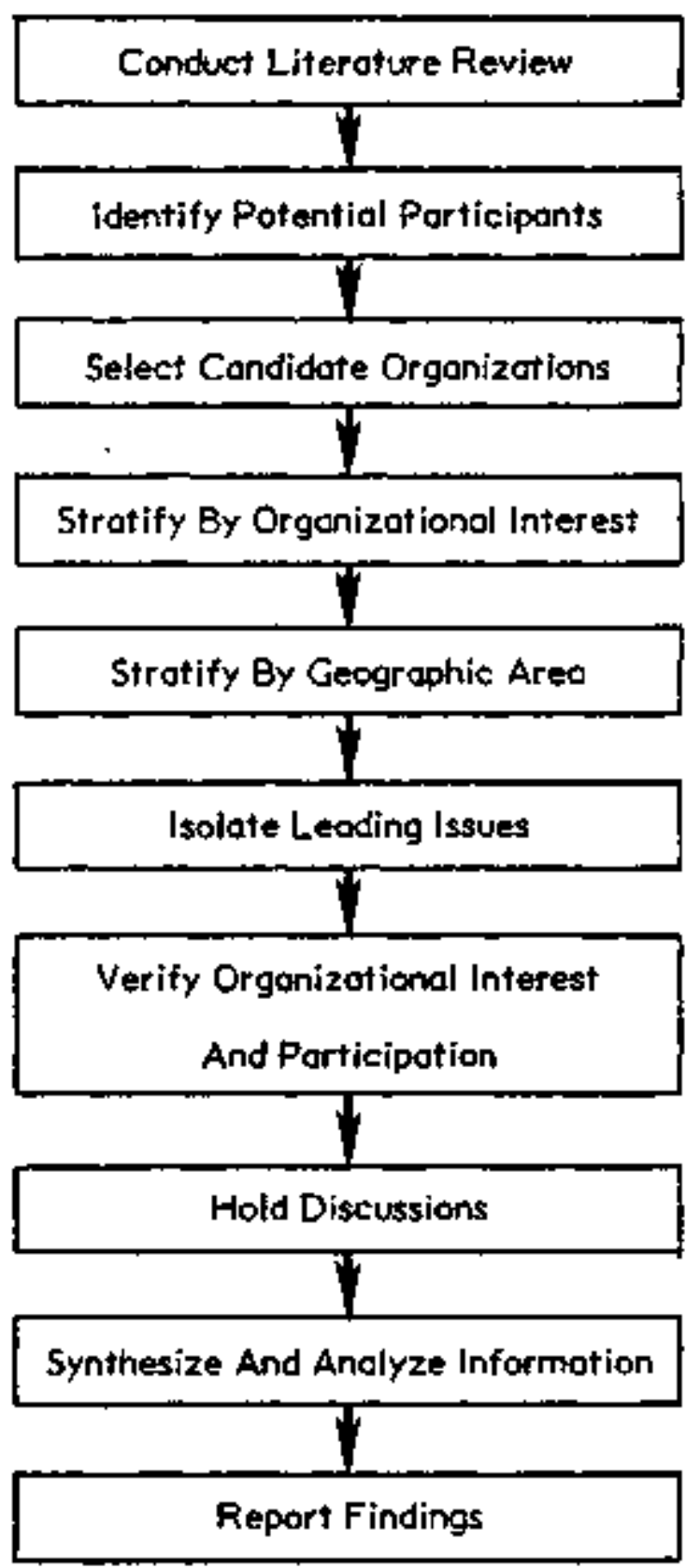

$-22$ 
financing, os well as budgeting processes for the autamotive industry. Literature describing existing Federal loan guarantee programs was reviewed (see Appendix B).

\subsection{Identificotion of Potential Study Porticiponts}

Many componies are examining alternatives to today's ICE. However, only

a few are working toword commercial production of the gas 'turbine and Stirling engines, the most promising of advanced aftomotive propulsion systems.

With the assistance of several sources such as trode associations, university reseorch ond development programs, and referrals from severol other agencies, 0 comprehensive listing of orgonizations potentially interested in AAPS wos compiled. This list was then combined with a review of all entities under the eppropriate Standard Industrial Classification listing to produce o composite tisting of 1172 industrial organizations or individuals possibly interested in the research and development of advanced automotive propulsion systems.

Similarty, 983 potential financial participants were identified. This number included commercial bonks, irvestment bankers, securities dealers and brokers, and financial pockaging houses. Many of those identified hod exposure to Federal loon guarantee programs, and many were familiar with tronsportation energy related progroms.

In addition, o list of individua's and institutions such os universities and reseorch organizations wos compiled. This group consisted of 282 contocts, and when combined with the industry and financial groups, brought the total number of identified organizotions or individuals to 2,437 .

\subsection{Identification of lssues}

To identify issues which would be germane to grow discussions, the identified organizations and individuats were contacted and invited to propose topics. Eighty-one replies were received from orgonizotions and individuals considered to be leoders in their respective fields and whose individual opinions reflect thase of the automotive industry and financial conmunity (see Appendix C). Of the 81 respondents, 61 expressed a desire and intent to porticipote in group discussion sessions. The respondents who chose not to attend the group discussion 
sessions were mainly representotives of the financial community. These individuals provided information through individual discussions, and their comments were considered in this report.

During the discussions, responses coincided with organizotional interests. The specific issues identified were:

- Industry issues

- Stage of development

- Type of financial incentive assacioted with stoge of development

- Fuel economy

- Identificotion of early production companies

- Major development bottlenecks

- Role of component monufocturers in development octivities

- Finoncial issues

- Extent of financial community participotion

- Full faith and credit

- Paymerst tipon default

- Interest rotes for guroronteed loans

- Repayment problems

- User charges

- Provisions for cost overruns/escalation

- Project financing versus copor ate finorking.

On the basis of the issues identified, o preliminary program outline wos formulated and submitted to the 61 parties who had expressed intent to participate in growp discussions (identified by an osterisk in Appendix C). New York, Chicago, and Los Angeles were selected as sites for growp discussion sessions after direct contoct was mode with each potential ottendee to determine mutuolly occeptable geographic locations. (The Los Angeles session was subsequently concelled becouse of a general lack of inferest.) 
Finally, after alt planning and arrangernents had been completed, a firm list of issues along with the times and ploces of the discussions wos forwarded to eoch of the 6 I respondents.

\subsection{Individual and Group Discussions}

The following information was derived from individual and group discussions with those organizotions and individuats listed in Appendices $C$ and $D$. While afl the thoughts expressed and comments made contributed to the study objectives, the conversotions have been condensed to the essential points an which there was a consensus and to the opinions expressed which were considered to be particularly noteworthy. The salient points brought out during individual and group discussions are categorized into two ports: automotive and component monufacturers, ond financial institutions.

Comments and opinions from representatives of the outomotive industry are briefly summarized in the following statements.

- While there is much inferest in the development of odvonced propulsion systems, there is only a relatively smoll group that con moke o significont impoct on the needs of the Nation.

- Component marufocturers are relatively few, and ore normally oligned with one of the major outomotive producers who do not want to develop specialized and expensive "in-house" copobilities for component monufocturing.

- There is a need to develop ceramic components capoble of withstonding extremely high temper otures in gos turbine engines.

- While high quality ceramic somples can be produced under controlled conditions, large production runs result in a great variance in properties.

- There is a need to develop suitable replacernent moteriols for the high-grode stainless steel now required for Stirling engines. This is important in reducing production costs.

- Limited production of automobiles with advonced propulsion systems is possible in the mid 1980 's, but full production is not expected earlier than the $1990 \mathrm{~s}$ without F ederal incentives. 
- Realistic cost projections for components ore difficult due to lack of experience with lorge, 'scale production of new component materiols.

- Total costs of AAPS development from the conception to full production is estimated at $\$ 2$ biltion, of which about one-fourth is associoted with component design and praduction capability.

-. The morket outlook of the AAPS industry is one of coution in light of the morket faiture of the turbo-charged engine. Industry wilt initially proceed with market anglyses, limited production, and development of limited mointenance and servicing infrestructure requirements. Industry will only tool up for mass production if there is reasonable assurance that a market for AAPS existsts.

- One of the three mojor manufocturers felt there could be a very definite side benefit in hoving on authorized guorontee program. It could help sustoin momentum during the commercialization phose of the AAPS progrom.

- A loon guarantee program would benefit component morufocturers by supporting increased product ion capacity once occeptable products are developed for use in AAPS. This, in turn, would help occelerate AAPS commerciolization.

- The AAPS industry is in the develooment stoge and many members feel that grants, contracts, and tax incentives are appropriote of this time. In oddition, some industry representatives believe that loan guarontees would be suitable as the state-ot-the-art improves and production nears reality.

- To attract the automotive incustry, any loan guarantee program must ossure minimal bureaucratic red tope and unnecessary Doperwork.

Inputs from representatives of the financial community are summarized is the following stotements.

- Introduction of o loon guarantee program should take place only when there is a promise of sutficient revenue generation to provide a meons for repoyment of the loon.

- In gerterol, the form of financial incentives should dovetail with the phase of development of ony given project. 
If a loan guarontee program were proposed:

- The guarantee should be bosed on the full foith and eredit of the United States.

- Borrowers and tenders should set the rotes of interest subject to approvol of the Secretary of Energy.

- It would be desirable to stipulate specific time periods in which poyment upon defoutt will be made, and stipulate that funds will be ovoilable for such payments.

If a loon guaronte progrom were implementedt

- The borrower and lender stoutld be ollowed to work toward rectitying problerns which may otherwise lead to defoult.

- Other provisions should be included to cover such ospects as user charges, withdrowal of guarontees, and cost overruns/escolotions. 
SECTION 4 CONCLUSIONS

1

$-29-$ 


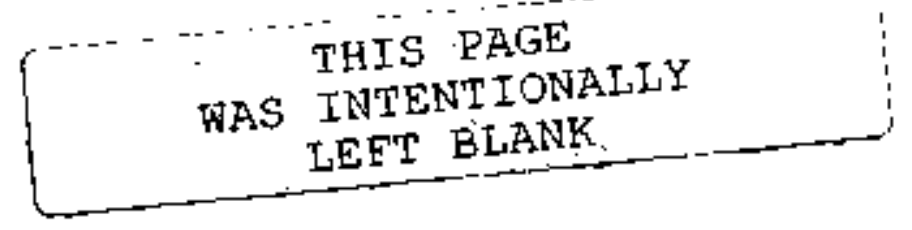

$-30-$ 


\section{SECTION 4}

\section{CONCLUSIONS}

\subsection{Introduction}

The conclusions presented in this section ore derived from information collected during the survey and study. These conclusions are based on analyses of ovoilable liferature and on individual and group discussions with representotives of the outomotive industry and the finoncial community.

\subsection{Bosic Issues}

The bosic issues oodressed in this survey and study are whetther and unjer what conditions Federal low guarantees would help stimulate AAPS development. In compliance with Title III of Public Low 95-238, the Deportment of Energy is now undertaking exponded research to develop and demonstrote odvonced automotive proputsion systems by 1983. Engineering development is focused on two types of advanced systems: the Broyton (gas turbine) and Stirling engines. Canclusions drown, therefore, first focus on the stote-of-the-art and outlook for commerciolization of these AAPS's. Follow-an conclusions then address the perceived applicability of loon guarontees to accelerate commerciolization.

\subsection{Technical Development Conclusions}

It is concluded that advanced automotive propulsion systerns offer the potential benefits of improved fuel economy, multifuel capabilities, and reduced exhaust emissions. This is supported by tectnical data derived from testing and evaluation programs dealing with baseline equigment. However, regardless of the prornise and optimism surrounding the gas turbine and Stirling engines, some tectnolagical aiffjeulties exist, and must be overcome before full line production can accur. These difficulties gre developmental in noture. While they may impede eorly full production, they are not insurmountale, and efforts to develop occeptable solutions are continuing.

The prerequisites to cormmercializotion of gas turbine automabiles are competitive fuel economies and competitive costs (compared to conventional internal cambustion engines). One barrier to achieving high fuel economy has been 
the furbine's poor port lood efficiency. Low cost and improved efficiency can be achieved simultoneousiy by utilizing ceramic materials in the hot sections of the gas furbine, since ceramics allow the turbine to operate at higher gas temperatures. With low-cost ceramics, there woutd not be a need for expensive, high-alloyed metals to sustain the higher temperatures. Comenerciolization prospects, therefore, are contingent on the development of oppropriote ceramic materials and on the improved aerodynamic performance of small turbomachinery.

The Stirling ergine development will utilize existing and near-term tectnology to achieve the project objectives. Fuel economy improvenents are expected to result primarily from development of a higher ternperature engine, the design and development of an experimental engine optimized for the outomobile application, and parollel component development. Stirling engines exhibit the potential of utilizing alternative fuels, inclusting olcohol and other nonpetraleum derived fuels.

Materials are also responsible for the major difficulties experienced by the Stirling engine marufacturers. Today, this engine requires a relatively lorge amount of high-grode stainless steel in its production. Uniess lower cost, alternative muterials con be developed for this engine, there ate questions of cost-effectiveness and, consequently, morket occeptance.

\subsection{Applicability of incentives}

It is important that the types of financial incentives used to stimulate AAPS commerciolization motch the types of financial requirements at any given phose of project development and the copital requir erments of the industry which will utilize that fechnology. Advanced outomotive propulsion systems are now in the engineering development phase, where finencial assistance could be oppropriote in the form of grants, contracts, cost sharing, and tax incentives. Indeed the Congress hos authorized the use of Federal contracts ond grants as incentives for research and development. Figure 4.1 depicts the relationships between the development phases and the time intervals when various types of financial incentives coutd be most appropriate. As the project moves into the demonstration phase, which is estimoted to lost through 1983, oppropriate types of Federal finoncial assistance could include grants, cost sharing agreements, tax incentives, or contracts for either the direct pur chose or lease of engines and/or vehicles. 


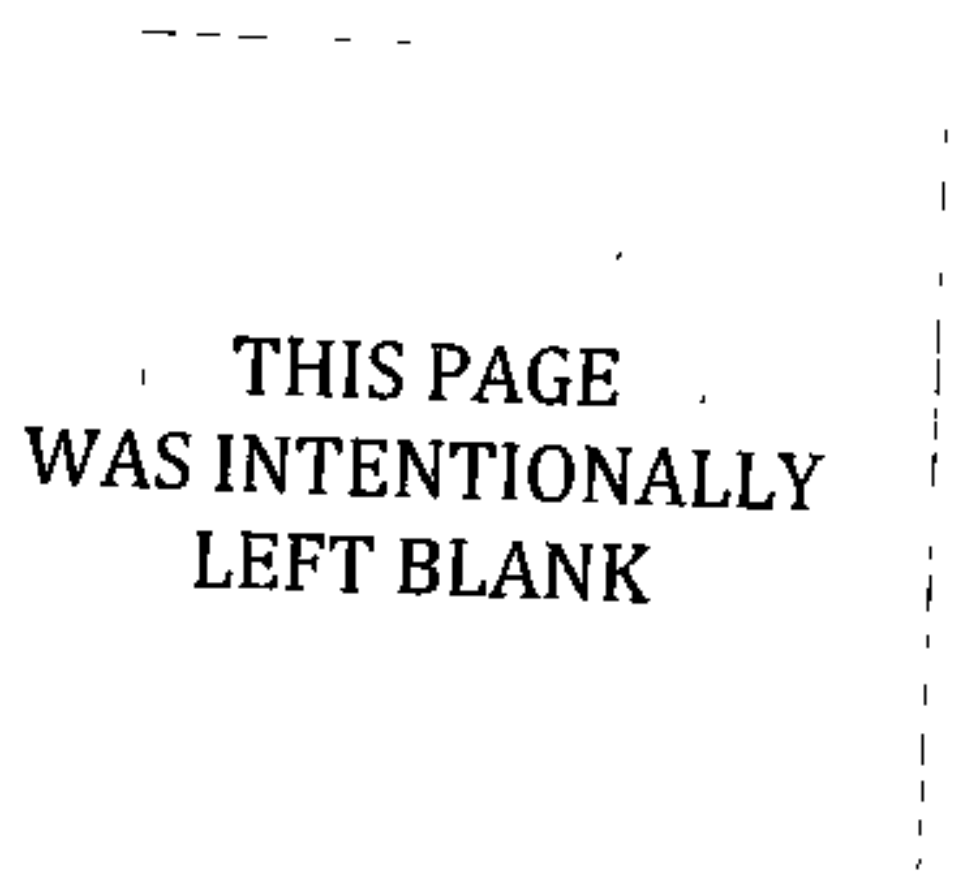




\section{RELATIONSHIP OF TYPE OF FINANCIAL INCENTIVE TO THE DEVELOPMENT STAGE OF ADVANCED AUTOMTIVE PROPULSION SYSTEM}

PGURE 4.1

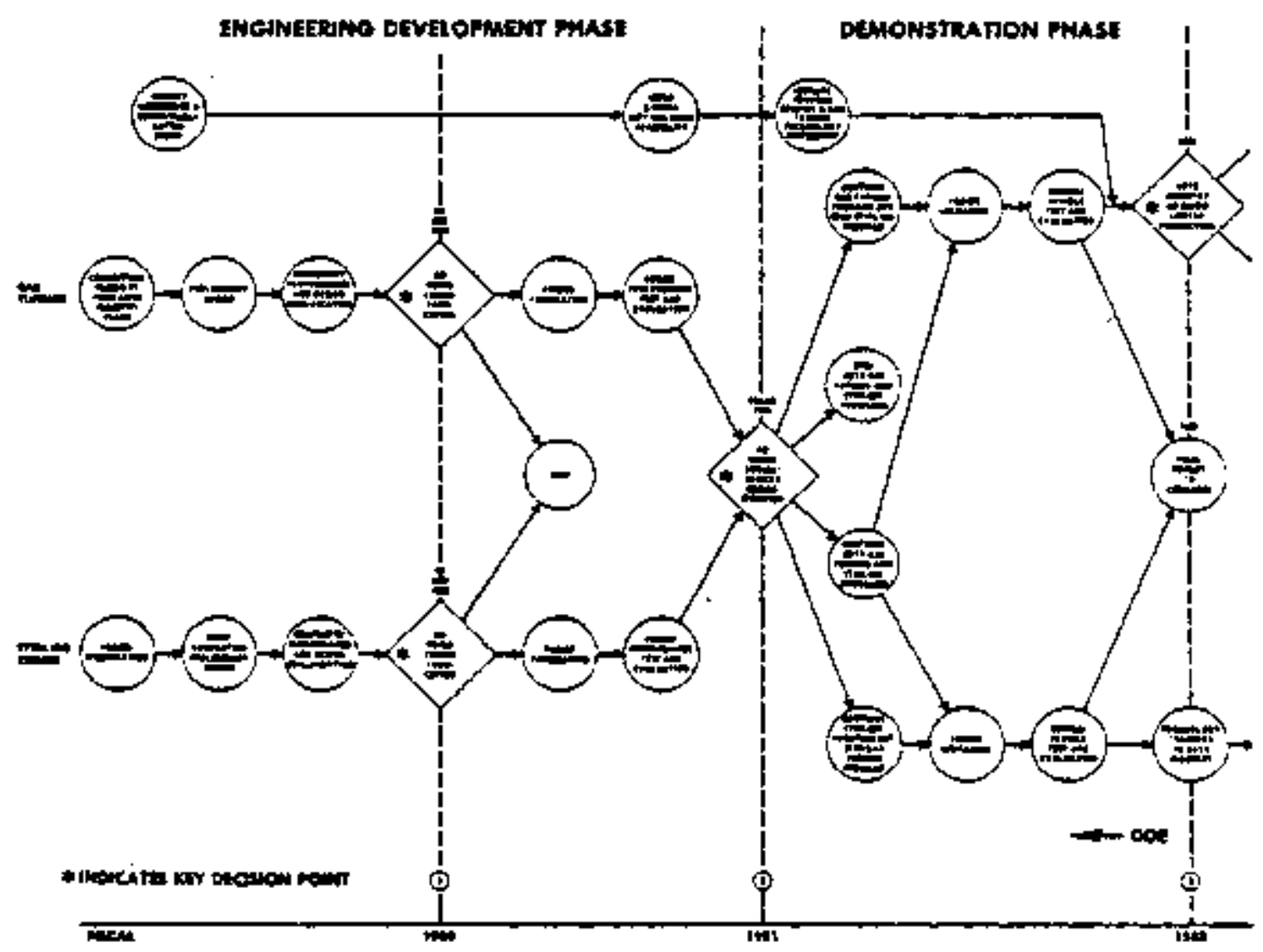

TrM OF INCENTIV:

TAX nerantives

CONIRACTS

cost shanese

cants:

moroust

ACREEMENT

DUECT LOANS

LOAN GUARMNTE:

mace simons

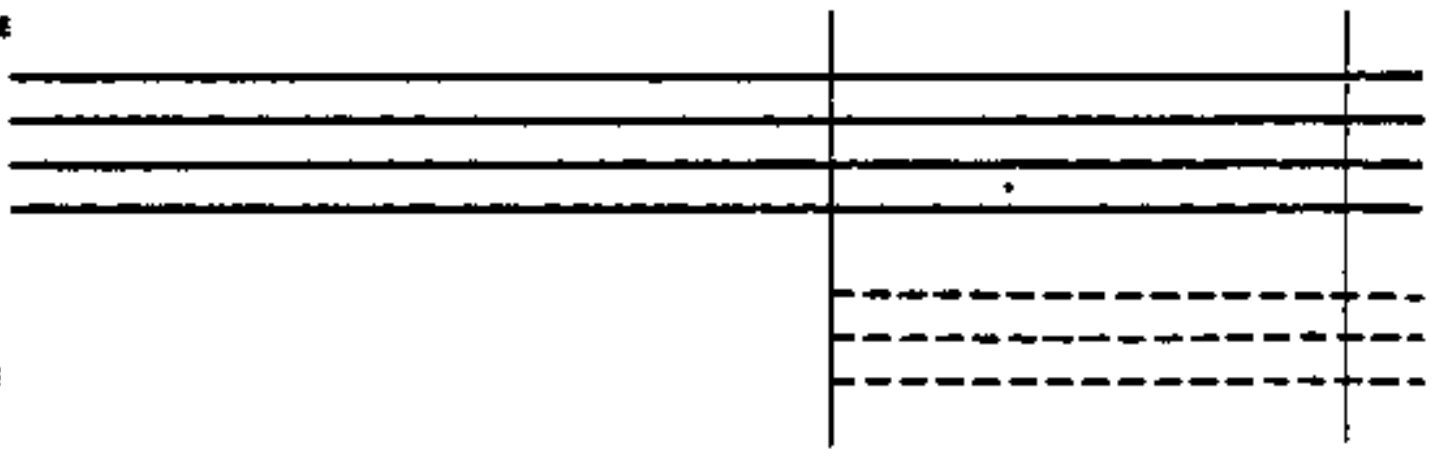

ktY;

NORMAL MLTHOD Of FINAMOAL AsSTSTAMCE

- - - ALttRNATE MITHOD OF ASS15TAML̀E 

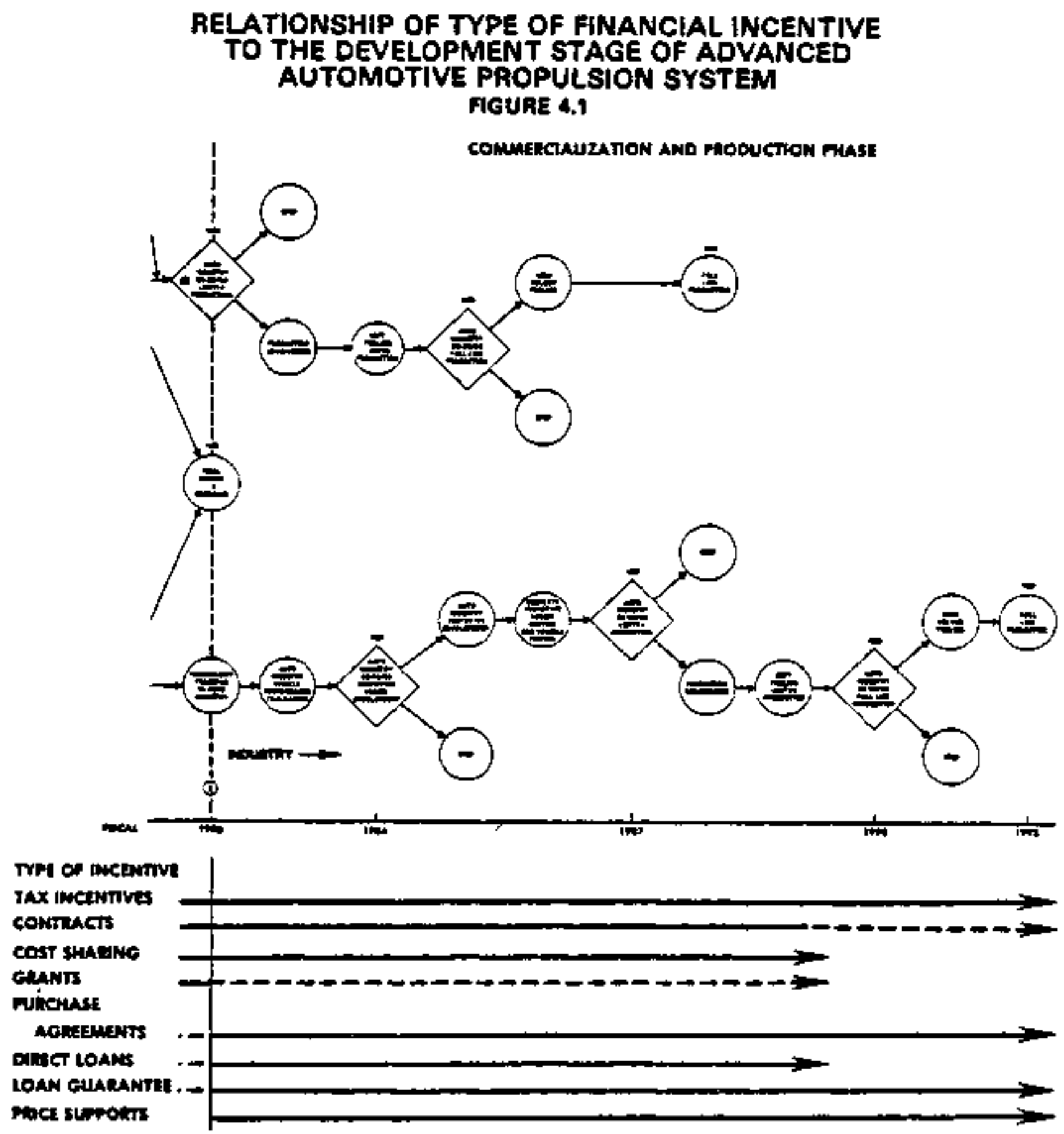

keY, 
During engineering development, large autornotive firms are copoble of supporting research efforts with corporote funds. it is expected that these firms will hove existing markets and products which can generate the necessary copital. Government assistance is not essential under these conditions. However, smaller firms moy require Federol assistorce to help overcome risks in the AAPS research and deveiopment phose.

Based on extensive discussions, it is corcludied that the financiot community would participate in a loan guarantee program to stimulate AAPS development in the demonstration and production phases if such a program provided adequate investment protection and safeguards. Porticipation by the financial cornmunity, however, would be contingent. upon evidence thot AAPS projects are at leost in the tooling up stoge and copable of gererating sufficient revenues to cover debt service over the period of the loon.

Industry projections indicate that AAPS development and demonstration will continue until the mid-1960's, at which time only limited production will begin. Full line production will not begin before the late 1980's or early 1990's. This suggests an extended period of time before loan guarantees would be applicable based an revenue generation potential. Federal loon guarantees ore most appropriate, however, where the industry needs assistance gaining occess to or protecting copital and when there is rectsonable assir ance thot sufficient reverues will be generated on a near-term basis (within two to four years) to permit a sctheduled repayment of financiol obligations.

The foregoing conclusions lead to the recommendations covered in Section 5. 
SECTION 5

RECOMMENDATIONS 


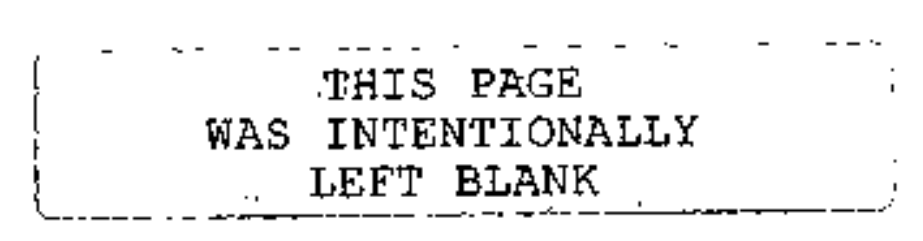

$-39$ 


\section{SECTIONS}

RECOMMENDATIONS

\subsection{Introduction}

Section 310 (b) of the Automotive Propulsion Research and Development Act (Title III, Public Low 95-239) requires that recommendations be mode as to whether, and under what conditions, advanced automotive propulsion systerns techmology reseorch, development, demonstration, ond commerciol ovoilability could be enhanced by Federal guarantee of finarcial abligations. This section presents the required recommendations based on the review of titerature, personal interviews, and individual and group discussions.

\subsection{Recommendations}

This report concludes that a loan guarantee program would not occelerate the current research and development efforts towards the commerciolizotion of AAPS systems. It is recommended, therefore, that consideration of legislation for authorizing Federal loan guorantees in connection with AAPS research and development be deferred.

While loon guarantees would not be effective incentives during AAPS research and development, DOE should evaluate the need for financial incentives, including loon guorantees, periodically. 
APPENDIX A

LITERATURE REVIEWED

$-4 i$. 
APPENDIXA

LITERATURE REVIEWED

Books

Buchonon, 3.M.

Public Finance in Democtatic Process, Chopel Hill: University of North Cordina Press, 1967.

Dible, Donild $M$.

Up Your Own Organization: A Hondbook on How to Start and Fingnce o New Business, Sonta Clara, Cofifornio: The Entrepreneur Press, 1974.

Eckstein, Otto

Public Finonce, Englewood Cliffs, N.J.: Prentice Holl, 1964.

Fenno, Richard $F$.

The Power of the Purse: Appropriations Politics in Congress, Boston: Little, Brown, 1966.

Golembiewski, Rabert T.t ed.

Public Sudgeting and Finance, Reodings in Theory and Proctice, Itasco, III: F.E. Peocock, 1968 .

Havernon, Robert H., and Margolis, Julius, eds.

Public Expenditures and Policy Anolysis, Chicago: Markhom Publishing. T970.

McRae, Alexander, ed.

The Energy Source Book, Germontown, MD: Aspen, 1977.

Nevitt, Peter K.

Project Financing, Chicogo: AMR Internationai, 1975.

Peters, G.H.

Cost-Benefit Analysis and Public Expenditure, London: institute of Economic Affoirs, T968.

Sowyer, John W., ed.

Sawyer's Gos Turbine Engineering Handbook, Volumes I, II, and III. Stemfort, Conn: Business Journols Incorporoted, 1972.

Technicol Reports

A Technology Assessment of the Tronsition to Advonced Automative Propulsion Systems, NTIS PB-272 705/5. 
Automotive Technology Stotus and Projections, Volumes I and II, Jet Propulsion Loboratory, Pasadern, Californio, 78-7!.

Federal Support for the Development of Alternative Power Systems: The General Issue and the Stirling, Diesel and Electric Coses, NTIS PB-263 $523 / 3$.

Financial Incentives Research and Lending Market impact Analystis, NTIS HCP/M38667 , UC-96.

Gos Turbine Engine Application in Transit Cooches, NTIS PB-272 608/I.

Highway Vethicle Systems, Fourteenth Summary Report, NTIS CONF-7805102, UC96.

Long Term Energy Alternatives for Autornotive Propulsion-5ynthetic Fued Versus Bgttery/Electric Systems, NTIS PB-262 513/5.

Periodicals

Lindsay, Franklin A.

"Finoncing High-Cost, High-Pisk Energy Development," Harvard Business Review, Volume 56, Number 6, (November-December 1978), pp. 16ł-\$70.

Marglin, $\mathrm{S}$.

"The Opportunity Costs of Public Investment," "Quarterly Journal of Economics, 77 (Moy 1963), pp. 274-89.

Peterson, John E.,

"Galloping Guarantees," Governmental Finance, Navember 1977.

Witson, Dovid $G$.

"Alternative Automobile Engines," Scientific Americgn, July 1978.

Documents

Clegen Air Act (42 U.S.C. 1857 et seq.).

Congressional Budget Office

Loan Insurance and Guarantee Programs: A Comparison of Current Practices and Procedures, February, 1978.

Executive Office of the President, Bur eou of the Budget (OMB)

Circular No. A.70 Legislotion on Federal Credit Programs.

February I, 1965.

Executive Office of the President, Office of Monogement and Budget

Circular No. A-B9 Revised, Cotalog of Federal Domestic Assistance.

December 3i, 1970. 
Executive Office of the President, Office of Management and Budget

Circular No. A-94 Revised, Discount Rates to be Used in Evaluating Time -

Distributed Costs and Benefits, March 27, 1972 .

Office of Monogement and Budget

Federal Register, "Evaluation, Review and Coordination of Federal and Federally Assisted Programs and Projects" January 13, 1976.

Public Low 93-224

The Federal Financing Bank. Act of 1973.

Subcommittee on Economic Affairs

Committee on Banking, Finance and Urban Affairs, Washington, D.C.

Catalog of Federal Loan Guarantee Programs, U.S. Government Printing Office, September, 1977.

Transportation Energy Conservation Division

Office of Assistant Secretary for Conservation and Solar Applications. Advanced Automotive Heat Engine Systems Development Project, Draft. Decernber 1, 1978 .

$-45$ 
APPENDIX $B$

FEDERAL LOAN GUARANTEE PROGRAMS

AND

FEDERALL Y INISURED LOAN PROGRAMS

$-47$ 


\section{APPENDIX $B$}

\section{FEDERAL LOAN GUARANTEE PROGRAMS}

Deportment of Agriculture:

Business and industriol loons

Emergency livestock line of eredit guarantees

Form ermergency loan progrom

Form operoting loons

Form ownership loons

Individual horneowners loons, loons for housing and building on potentiolly adequate forms

Rural electrificotion toon guarontees

Rural telephone ioan guorontees

Soil and water conservation loan and loan insurance program for individuals

Department of Commerce:

Business deveiopment loan guarantees

Cocstol energy impoct progrom

Federal ship financing guarontees

Fishing vessel obligation and gurantee program

Trade odjustment ossistance for communities

Trade adjustment assistance for firms

Deportment of Defense:

The Defense Production Act

Foreign militory credit soles

Department of Energy:

Electric and hybrid vehicle research, development, demonstration, and praduction, loon guorantee progrom

Goothermol loan guar antee progrom

Coal loon guarantee prograrn

Energy conservation and rersewable resource obligation guarontees program 
Department of Health, Educotion, and Welfare:

Construction and modernizotion of hospitals ond other medical facilities Construction of health professions teoching focilities

Department of Housing and Urbon Development:

New communities loan guar ontees

Department of the interior:

Bureas of Indion Affairs loan guarantee program

Grorantee of certain obligations of the Guom Power Authority

Guorantee of Virgin Islands bonds

Guarantee of Virgin Islonds loans

Department of Stote:

Agriculfural and productive credit and self-help community development program Housing guorartee progrom

Depar tment of Transportation:

Aircroft loon guorantee progrom

Emergency Roil Services Act of 1970 guarontee of trustee certificates

Loon guarontees issued under the Rail Passenger Service Act of 1970

National Copitai Transportation Act revenue bond gurantee program

Deportment of the Treosury:

Emergency Loon Guorontee Baord

Envirormental Protection Agency:

Loon guarontees for construction of treatment works

Export-Irmport Bonk:

Cooperative financing facility (CFF) - parteipating financial institution guarantees and guarantees on certificates of ban participation

Financiol guarontees

Medium-term commercial bonk guarontees 
General Services Administrotion:

Federd building loan gworantees

Real property guarontees

Over seas Private Investment Corporation:

Investment guorontees

Small Business Administration:

Air pollution control loons

Base closing economic injury loons

Coal mine heolth ond safety loans

Disploced business loons

Economic injury disoster loans

Economic apportunity loons

Emergency energy shartage economic injury loons

Hondicoped assistance loons

Meat and poultry inspection loans, consumer protection loans

Occupotionol safety and heolth loans

Physical disoster

Regular business Joors

Small business investment compony program

Sur efy bond guar ontee

Strategic orms economic injury loans

Woter pollution cantrol loons

United States Railway Association:

Interim maintenonce and improvement loons

Loans for railiroods in reorganizotion

Loons to State, local, or regional transportation authorities

Veterons Administrotion:

Veferons housing loans

Veterons mobile home loons 


\section{FEDERALLY INSURED LOAN PROGRAMS}

Deportment of Agriculture:

Association irrigation and drainoge loons

Business and industrial Joans

Community focilities loans

- Domestic farm lobor housing toon prograrn

Form ennergency loan program

Form operoting loons

Form ownership loons

Grazing association loans

Indion tribes and tribal corperotion loons

Individual homeowners loons, loons for housing and buildings on

potentialty adequate forms

Recreation focilities toans

Resource conservotion and development loans

Rural eiectrification loans

Rural housing disaster loons

Rural housing site loans

Rural rentol housing loons

Rurol tejephone toans

Soil and water conservation loon and boan insurance program for individuals

Very-low income housing repair loans

Watershed protection and flood prevention loans

Department of thealth, Education, and Welfare:

Student loons

Department of Housing and Urban Development:

Homes for certified veterans

Mor tgoge insur ance for horre purchoses

Hornes for disoster victirns

Homes in outlying areos 
Home improvement loon insurance for housing outside urban renewal areas Mobile home parks

Mortgage insurance for rental housing

Development of soles-type cooperative projects

Investor-sponsored cooperative housing

Management type cooperative projects

Mortgage insurance for purchase of soles-type cooperatives

Cooperative housing insurance, management type projects - supplementory loons

Homes in urban renewal areas

Mortgoge insurance for rental housing in urbon renewal areas

Homes for low- and moderate-income families

Mortgoge insurance for rental housing for low- and froderate-income families

Mortgoge insurance for rental housing for moderote-income fomilies

Rehobilitated housing for low-income families

Conversion of rental housing projects to condominiums

Conversion of rental, housing projects to cooperotives

Morigoge insurance for servicemen

Housing in older, declining oreas

Mortgoge insurance for the purchose or refinancing of existing multifomily housing projects

Mortgoge insurance for rentol housing for the elderly

Mortgoge insurance for nursing home and intermediote care focilities

Mortgage insurance for experimental homes

Mortgoge insurance for experimentel projects ather than housing

Mortgoge insurance for experimental rental housing

Mortgoge insurance for purchase of units in condominiums

Construction or rehabilitotion of condominium projects

Hornes for lower-income families

Acquisition and rehabilitation of hornes for resole to lower-income fomilies

Purchase of rehabilitated hornes by lower-income fomilies

Rentol and cooperative housing for lower-income fomilies

Mortgage insurance for speciol credit risks 
Mortgage insur once far purchase by homeowrers of fee simple title from lessors Multifamily coinsurance

Single-fomily coinsurance

Experimental $t$ inancing groduated payment

Armed services housing for civilion employees

Historic preservation loons

Mobile home loan insurance

Section 2 - Property improvernent loan insurance for improving ol l existing structures and bujlding new nonresidentiol structures

Title $X-$ Land development and new cornmunities

Title XI - Group proctice focitities

Deportment of the interior:

Bur eou of Indion Affairs toon insurance progrom

\section{Export-Import Bonk:}

Medium-term export credit insur ance

Short-term export credit insurance

Veterans Administration:

Veterans housing loons

Veterans mobile home ioans 
APPENDIX C

INTERESTED PARTIES

$-55$ 
APPENDIX C

\section{INTERESTED PARTIES}

* Advonced Mechanicol Technology, inc. Dr. Wolter Syniuta

* American State Bank Mr. William Dean

* American Transit Corp. Mr. Poul Ballard

* Ationtic Richtield Co. Mr. William Schlarb

* Autotronic Controls Corp. Mr. Jock Priegel

* Boche, Holsey, Stuart, Shields, Inc. Mr. George Reis

- Bajes-McCoin Tractionmatic, Inc. Mr. Kert Bales

Bankers Trust Co. Mr. Daniel F. D. McKiniey

* Batfelle Columbus Lab. Mr. John T. Herridge

* Bearn Produets Marufocturing Co. Mr. Robert Mockenzie

* Bombardier Incorporated, MLW Ind. Mr. J. Bryon Whittinghom

Business Fingnce Center of Americo, Inc. Mr. G. Al Perrine

Copital Nationol Bank Mr. Fred M. Haston, Jr.

* Cari Marks and Compony, Inc. Mr. Stephen Axeirod

* Chrysler Corp. Mr. Charles Wogner

Citibank, N.A. Mr. Johan de Voogd
* Commercial Bonking $M r$. Robert Plerce

- Continental Conveyor and Equipment, Inc. Mr. Jisn Burgess

Continental IItinois National Bank and Trust Co. of Chicogo Mr. Dennis L. Winget

Crocker National Bank Mr. Glenn W. Berry, Jr.

* Dona Carp. Mr. Lowrence Harrison

- Detroit Bonk and Trust Mr. Lawrence Fitch

* Detroit Diesel Altison - General Motors Mr. Dan johnson

* ERG, Inc. Mr. Glendon Benson

* Falcon Reseorch and Development Co. Mr. H. T. McAdams

Ford Motor $\mathrm{Co}$. Mr. D. Ronzi

* Foster-Miller Associates, Inc. Mr. Ross Olonder

* H. Y. and Associates, tnc. Mr. P. J. Wolsh

* Ideal Corp. Mr. Dovid Reiss

* Kinergy Reseorrch and Development Ms. Laura Omohundro

* Kumm Ind. Mp. Emerson Kumm

* Represents thase interested parties which indicoted on intent to attend a discussion session. 
- Letwron Brothers, Kutin, Loeb, Inc. Mr. Kevin MeCorthy

* Monufocturers Hanover Trust Co. Mr. T. Dovid Quarles

* Moth Sciences Nor thwest Mr. Robert Toussig

- Mechonical Technology, Inc. Mr. Otto Decker

Merrill, Lynch, Pierce, Fenner, and Smith, Inc. Mr. Gordon Watson

* Miller Electric Manufocturing Ca. Mr, Jock Honus

- Monsanto Co. Mr. F. H. Langenfeld

* Onan Corp. Mr. Peter Cerf

* Peco Enterprises, Inc. Mr. Frank Granados

* Peterbilt Motors Co. Mr. Virgil Pound

- Philips Lab. Mr. Alexonder Daniels

- Power-Motic Corp. Mt. Loird B. Gogins

Public Secutities Assn. Mr. Robert Kline

* Research Trons-O-Matic Mr. Eric Logercrantz

* Rlodes Chemical Corp. Mr. Hal C. Fetsher

* Safeco Corp. Mr. Ronold Spoulding Showrmit Bonk of Boston, N.A. Mr. Potrick Connolly Society of Automotive Engineers Mr. Thomos Northrup

- Sperry Vickers Mr. Robert Brown
* Standard Thornson, Inc. Mr. Bockmon Wong

State Street Bonk and Trust Ca. Mr. William McK. Rust

- Sunpower, Inc. Mr. Richord Lomprey

* Switches Mr. Dominick Corlino

The Chase Manhatton Bank, N.A Mr. Sheldon Sixf in

The Citizens and Southern Notional Bank Mr. Jay M. McDonald

* The Cleveland Trust Co. Mr. D. R. Collister

The Fulton Notional Bank of Atlanto Mr. Frorklin L. Burke

* The Gorrett Corp. Mr. W. E. Sullivon

The Robinson-Humphrey Compony, Inc. Mr. Larry C. Willigms

* Tierney Monufocturing Co. Mr. Donald A. Molohn

- Transmission Research, Inc. Dr. Algírdas L. Nasvytis

- Transmission Technology Co Mr. Dezi Folento

- Union Planter National Bank Mr. Alvin Sole

* Unique Mobility, lnc. Mr. John Gould

* University of Wisconsin Dr. Andrew Frank

- Virginia Polytechnical Instítute Mr. Wolter OBrien, Jr

W. Dobbs and Co. Mr. Nelson Taylor

* Walker Morufocturing Co. Mr. Robert Bolluff 
- Wayne State University

Dr. T. Singth

- White Engines, lnc.

Mr. Clifford A. Fordhom

Williom M. Brobeck and Assr.

Mr. Worren Eukel

Williams Resegrch

Mr. Wiltiam Bourer

Williams Research

Mr. William Chopmon 


\section{APPENDIXD}

\section{POINTS OF CONTACT}

$$
-61 .
$$




\section{APPENDIX D}

\section{POINTS OF CONTACT}

Iltinois Institute of Technology

Reseorch institute

Dr. Durscon Yotes

Willioms Research

Mr. William Baurer

Mueller Associates

Mr. Thomas Timbario

United Stirling of Sweden

Mr. K. Rosenquist

University of Santo Clara

Dr. P. Delescu

industrial Turbines International

Mr. Robert Scholl

State Street Bank \& Trust Compony Mr. Williom Mck. Rust

Bonkers Trust Compony

Mr. Daniel F. D. McKinley

Merrili, Lynch, Pierce, Fenner, \& Smith, Inc.

Mr. Gordon R. Watson

The Robinson -Humphrey Compony, Inc.

Mr. Lorry C. Williams

W. Dobbs and Company

Mr. Nelson Toylor

Continental Illinois National Bank \& Trust

Compony of Chicogo

Mr. Oemis L. Winget

Business Finonce Center of America, Inc.

M. G. Al Perrine

Securities \& Exehonge Cornmission

Division of Investment Manogement

Mr. George Woshburn

5ecurities \& Exchange Commission

Division of Corporate Finance

Mr. John Mooney

Federal Rejerve System

Division of Research and Statistics

Mr. Pout Boltz
Wiltioms Reseorch

Mr. William Chopman

Mullier Associates

Mr. Andrew Forker

Office of Technology Assessment

Department of Commerce

Mr. H. James Leach

University of Woshington

Dr. Williom Martini

Ford Motor Compony

Mr. D. Ronzi

Society of Automotive Engineers

Mr. Thormas Northrup

Showmut Bonk of Boston. N.A

Mr. Patrick F. Connolly

Citibank, N.A.

Mr. Johon de Voogd

The Chase Monhattan Bank, N.A

Mr. Sheidon Sixfin

The Fulton National Bank of Atlanto

Mr. Franklin L. Burke

The Citizens \& Southern Notional Banis Mr. Jay M. McDonald

Copital National Bank Mr. Fred M. Heston, Jr

Cracker Notional Bank

Mr. Gienn W. Berry, Jr.

Federal Depasit Insurance Corporation

Mr. Robert Egger

Securtties \& Exchange Commission

Division of Economle Reseorch

Mr. Paul Livingston

Comptroller of the Currency

Bonk Organization and Structure

Mr. Hhogh Eggleton 
Federaf Deposit Insur ance Company Bark Division

Mr. John McCarthy

Notional Association of Securities Deolers

Government Guoronteed Loan Deolers Association

Mr. Gordon Watson

Ceranic Systems, inc.

Mr. E. Herman

Corning Glass Company

Mr. J. Lonning

GTE-.-Sylvanio

Mr. irvin Eríckson

Norton Company

Mr. Moe Tortie
Securities \& Exchonge Commission Division of Morket Regulation Mr. Jeffery Stee!

Public Securities Association Mr. Robert KJine

Kawecki-Berylco Industries, inc. Mr. R. J. Longenecker

Orsharky Transmission Corporation Mr. W. E. Weseioh

Corborundum Cormpony

Dr. E. H. Kroft

Coors-..-Porcelin

Mr. Coubrough 